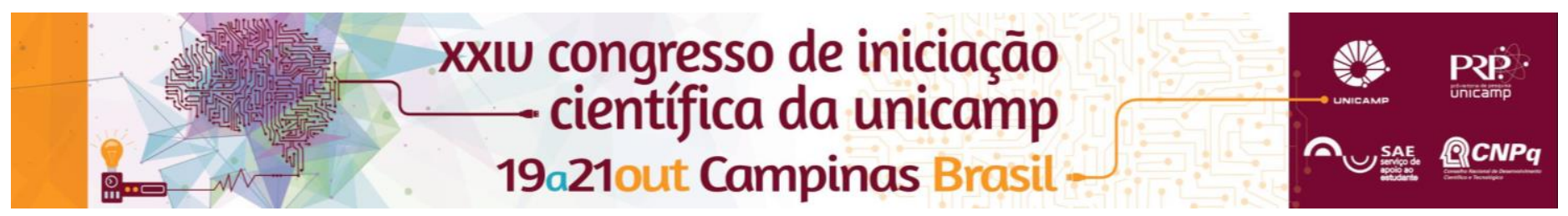

\title{
Guia Arquitetônico de Campinas
}

\author{
Andrey Cintra Gomes Marcondes* Ana Maria Reis de Goes Monteiro
}

\begin{abstract}
Resumo
Campinas apresenta uma história marcada por diversas transformações que perpetuaram nos períodos do café até o modernismo. Das arquiteturas existentes, muitas estão preservadas e muitas esquecidas, pelo abandono e desconhecimento, sendo grande parte dos edifícios tombada pelo CONDEPAAC. A cidade passou pelo período açucareiro, logo após sua fundação; depois investiu na agricultura cafeeira, culminando no auge da economia do Estado de São Paulo, superando por alguns anos a própria capital paulista. Esse auge teve curta duração, quando uma epidemia de febre amarela atingiu a cidade. A recuperação ocorreu rapidamente e logo incidiu para a Modernidade, com o Plano de Melhoramentos. A carência de interesse e conservação pelo patrimônio motivou este trabalho a idealizar um Guia Arquitetônico do centro histórico de Campinas, com o objetivo de recuperar o interesse da população em preservar e utilizar os edifícios, divulgando a história da cidade, para que a população tenha conhecimento do passado em que caminha diariamente. O Guia Arquitetônico apresenta os edifícios com breve história da cidade, através de pesquisa histórica e catalogação dos edifícios, registros fotográficos e coletas de fotos antigas, além da elaboração do folder gráfico.
\end{abstract}

\section{Palavras-chave:}

Campinas, Guia Arquitetônico, Patrimônio histórico

\section{Introdução}

A história de Campinas foi marcada por diversas transformações, desde o período cafeeiro ate 0 modernismo. Muitas das arquiteturas existentes estão preservadas e muitas esquecidas, pelo abandono e desconhecimento. O CONDEPAAC tombou grande parte dos edifícios. A carência de interesse e conservação pelo patrimônio motivou este trabalho a idealizar um Guia Arquitetônico do centro histórico de Campinas, com o objetivo de recuperar o interesse da população em preservar e utilizar os edifícios, além de divulgar a história da cidade, para que a população tenha conhecimento do passado em que caminha diariamente.

\section{Resultados e Discussão}

O resultado do projeto teve como base a análise histórica da cidade e catalogação dos edifícios históricos tombados pelo CONDEPAAC. Também foram registradas fotografias atuais dos edifícios, além de coletas de fotografias antigas da história da cidade. A partir desses dados, foram sistematizados mapas e perspectivas para a elaboração do Guia Arquitetônico.

Parte Histórica:

O Bairro do Mato Grosso das Campinas era o nome do pouso que percorria o porto de Santos à Goiás no caminho do Ouro. A terra fértil proporcionou produção de alimentos e moradias. Com o tempo tornou-se Vila São Carlos, passou a produzir açúcar e começou os primeiros traçados e construções: Igrejas. Com a chegada do café, a Vila destacou-se economicamente, investindo bastante em educação, cultura e saúde. Passou a ser cidade, com o nome de Campinas. A produção de café foi bastante intensa, chegando a superar em alguns anos a própria capital paulista. $O$ auge teve curta duração, quando a epidemia de febre amarela atingiu a cidade, pois padecia de cuidados e saneamentos básicos. A febre dizimou a cidade em um quarto. Sua recuperação ocorreu rapidamente, trazendo o retorno das indústrias perdidas na epidemia. Logo ocorreu a recuperação arquitetônica da cidade. A influência do modernismo nos Estados Unidos e Europa, nos anos 30, repercutiram também em Campinas, provocando a restruturação do plano urbano da cidade, através do Plano de Melhoramentos, onde foram demolidos alguns edifícios antigos para dar lugar a avenidas largas e arranha-céus, símbolos da modernidade. Após essa fase, a região central da cidade não teve mais transformações. Abaixo, um dos resultados do guia.

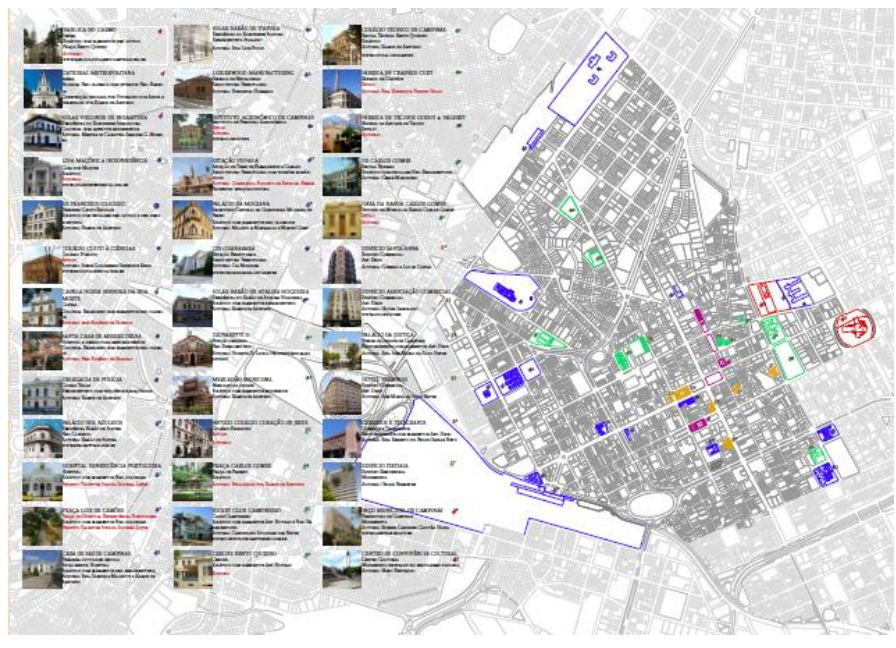

\section{Conclusões}

O trabalho projetou um folder gráfico, que revela breve história da cidade, através de catalogação dos edifícios e registros fotográficos ampliando 0 interesse da população.

\section{Agradecimentos}

Agradeço a orientadora e ao $\mathrm{CNPq}$ pelo apoio a este projeto. Dedico este trabalho a Campinas e todos os Campineiros. 